International Review of Research in Open and Distributed Learning Volume 17, Number 6

December - 2016

\title{
Assuring Quality in E-Learning Course Design: The Roadmap
}

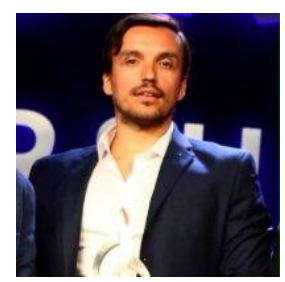

Dimitrios Vlachopoulos

Laureate Online Education \& European University Cyprus

\begin{abstract}
Quality Assurance (QA) concepts and applications in Higher Education (HE) emerge from evolving meanings related to HE's dynamic relationship with social, economic, cultural, and technological developments. The latter has been redefined by the growth spurred by the forms distance and online education acquired during the last decades. Creating a roadmap with clearly articulated meanings of quality and consistent key actions fills a need for the involved communities to reground the research, policymaking, and the related discourse. Our current work consists of a thorough meta-analysis on all available research in every identified pertinent field. It is a qualitative review of the concepts, definitions, and approaches about quality in general, but also specifically, in e-learning in HE, as they have globally appeared in peer-reviewed journals, government reports, and web pages. As we left no stone unturned in enquiring regarding the meanings, uses, evolution, and applicability of the revealed variables it is our hope that the roadmap we provide here will guide future research and support policy-making in the field. The present study is part of the research project e-learning Quality Assurance Design Standards in Higher Education (e-QADeSHE), which was funded by Laureate International Universities as the winning research project for the International David Wilson Award for Excellence in Teaching and Learning (2015 edition).
\end{abstract}

Keywords: distance education, online education, e-learning, quality assurance, quality standards, higher education, course design 


\section{Introduction}

During the last decades, educational systems, particularly in Higher Education (HE), have been almost redefined. Such reforms, inevitably, call for a reassessment of notions and operational definitions of quality, along with a host of related concepts. This reassessment is aligned with the deeper core of HE's reforms: improved effectiveness and attunement to emerging social demands, while accommodating competitiveness and accountability trends.

Terms and concepts that had previously been exclusively salient in Economics are currently gradually appearing in lay talk when discussing HE. Moreover, quality and evaluation, efficiency, competitiveness, accountability, the educational customers, and similar concepts are now foci of sophisticated analysis for professionals responsible for policy creation in HE.

The educational field, both in the design of objectives and activities and in the outcomes, actively mirrors and evolves with social, economic, cultural, and technological developments. It is, thus, imperative, that mechanisms of systematically monitoring quality improvement and effectiveness are put in place. To this end, we propose that conceptually delineating the terms "quality in HE" is vitally important. Furthermore, we argue that specifically venturing into the delimitation of quality in Distance Education and quality in Online Education are an essential aspect of such endeavor.

\section{Research Approach}

The present study's main aim is to create the roadmap for quality in e-learning in HE. Such a result would engender a framework for future activity in this sector, thus, fulfilling a major current need in the related scientific communities. To this end, we present here a meta-analysis, which is a standardized approach, on the topic. We provide a qualitative review of the concepts, definitions, and approaches that have been previously researched. We performed an extensive literature review in indexed and peer-reviewed journals, government reports, web pages, and books to collect and review all available definitions and approaches about quality in e-learning in HE. In a field as recent as quality in e-learning, which is constantly evolving at a dizzy rate (Sangrà, Vlachopoulos \& Cabrera 2012), it would not be worth analyzing literature exhaustively over the last five years, given that some considerations fall into disuse and become obsolete. Nonetheless, before starting to review the literature, it was thought worthwhile to re-examine the conception of quality in (online) Higher Education before 2005 in publications by widely acclaimed and internationally recognized authors. The results of this review confirmed that many of their opinions would still be valid, and many of the authors who have published work on this subject, more recently have drawn on their contributions. The following key words were used for this research: e-learning quality, quality assurance in e-learning, quality standards in online/distance education, quality assurance in higher education, e-learning course design standards, e-learning standards, and conceptual investigations of the term quality. Additionally, quality assurance definitions were searched in English, Catalan, Spanish, French, German, Greek, Romanian, and Italian, which are the languages that are well versed by the author and the e-QADeSHE (e-learning Quality Assurance Design Standards in Higher Education) team. Despite 
the fact that the literature review was conducted in eight different languages, most of the references that were indexed in the most important data bases were in English. This confirms Lillis and Curry (2015) who underline that the dominance of English as the language of scholarly publishing puts scholars under increasing pressure to publish their research in English. The results of the meta-analysis were used to design the roadmap which can guide future research and support policy-making in the field.

\section{Conceptual Investigations of the Term Quality}

The achievement of excellence has been considered as the cornerstone of universities. Recent Zeitgeist developments, however, have raised an urgent need to functionally revisit and conceptually distill previous notions of quality. For instance, universities enjoy an ever-increasing autonomy, while many governments provide university institutions with flat rate financing, in return for accountability. However, the term "quality" is elusive to define in fixed, palpable terms, as it may take on multiple meanings depending on the context within which it is discussed (Annis, Abdullah \& Islam, 2014; Dagles, 2008). Discussions on the quality of education have been found to often "suffer" from a lack of clarity and from the absence of a commonly accepted notion of what "quality" means (Commission Européenne, 2009; Prisacariou \& Shah, 2016). A possible explanation for such elusiveness is that the quality of education is not a concept inherently related to commercial parameters, but a concept that appears to be associated with intuition. A close examination reveals that there seems to be no collective perception of the term or a single way to examine it, but several possible theories and multiple approaches, all of which are based on widely divergent assumptions.

\section{Quality as a Multidimensional Concept}

According to Kontogeorgos (2012), the term is extended to reveal a set of features, which form into a Gestalt, offering a complete representation of a person, a system, a process, or a product. Similarly, we find "quality" as a multidimensional term, with no universal agreement on its definition, since each prospective "customer" focuses on a different feature of the product or service which they address as "quality" (Zavlanos, 2003). Importantly, quality does not equal perfection, as it merely provides a means to measure the satisfaction of certain criteria and requirements/standards which ensure it. Therefore, it is recognized as "a never-ending journey” (Sârbu, Ilie, Enache, \& Dumitriu, 2009; Schindler, Puls-Elvidge, Welzant, \& Crawford, 2015).

Martin and Stella (2007) distinguish two basic concepts of quality:

- Compliance with standards, when it is feasible to define and establish certain aspects of HE and to apply the same standards in all subjects and in all organizations, and

- Adjustment to the target, since institutions' and programs' objectives are different and their assessment is not based on mutually accepted and quantitative criteria, but, rather, depends on the analysis of the specific context. 
Bogue (1998, as cited in Conseil canadien sur l'apprentissage-CCA, 2009, pp.7-8) combines "perspectives" on quality common across HE institutions:

- limited supply, consistent with a conceptualization of quality as excellence and regarding HE as a "positional market" in which institutions compete for status,

- quality within mission, defined as "fitness for purpose," and

- value-added, or quality in results, defined by Astin (1985, as cited in Bogue, 1998) as the impact "on the students' knowledge and personal development and on the faculty members' scholarly and pedagogical ability and productivity.” (p.9)

Harvey (2008), somewhat similarly, proposes five definitions for quality, noting that it is synonymous with:

- Distinction, when it implies exclusivity and excellence but also achievement standards.

- Perfection or consistency, characterized as free of any defect and having the ability to render successfully with the first attempt.

- Fitness for purpose (mission), when assessing the ability to complete a task or a predefined function or whether that task or function is adequate.

- Value for money, when assessing the return on investment of the expenditure, as a measure of performance.

- Transformation, when assessing the added value of the educational experience according to the plan for students' development.

It almost seems that there are as many definitions of "quality" as the number of people who came up with them (Conseil Supérieure de l'Education de Québec-CSE, 2012). Consequently, it is rather apparent how University Education Quality Assurance could then become a polysemic term, since its meanings depend on the various contexts.

\section{Evolutionary Adaptations of Quality and their Impact on Quality Assurance Definitions}

Crucially, concepts of quality seem to have evolved over the years. Koslowski (2006, as cited in Nicholson, 2011) highlights that quality was particularly associated with excellence in the 1980 os and 1990s. This perspective was initially introduced by Harvey and Green (1993) and, currently, tends to mean adapting to the goal. This shift is reflected in a study for the Organization for Economic Co-operation and Development (OECD) by Tremblay and Kish (2008). The latter do not provide a strict definition for QA, but rather illuminate the concept's complexity. Tremblay and Kish (2008), retain Harvey's definition (2004; 2007), which states that QA is a process of establishing stakeholder confidence that provision (input, process, and outcomes) fulfills expectations and measures up to threshold minimum requirements, while admitting that the concept can also be described as a systemic, structured and continuous attention to quality in terms of 
quality maintenance and improvement (Vroeijenstijn, 1995), or as the policies, attitudes, actions and procedures necessary to ensure that quality is being maintained and enhanced (Tremblay \& Kish, 2008; Woodhouse, 1999).

This developmental trajectory encompasses the dual effects of Total Quality Management (TQM) processes, with a focus on efficiency, and of Management Processes, with a focus on end results. Their combination into functional designs allows for flexibility, since specific missions are also taken into account. As stated by Martin and Stella (2007, p.37), the "concept of quality, its creation and its functional implementation, has an obvious impact on how it will be ensured. The "QA" refers to the systematic activities carried out on a production system, so that the quality requirements for a product or service are met (International Standards Organization-ISO8402, 1994). Thus, the systematic measurement, the comparison with a standard, the monitoring of the procedures, and the necessary feedback with the aim to prevent errors and achieve improvement constitute activities that assure quality. In general, QA in HE refers to all the procedures and mechanisms that ensure the quality of programs, institutions, or national education systems. For Vlãscesanu, Parlea, and Grünberg (2004, as cited in Martin and Stella, 2007) for example, QA is a "universal term that defines a permanent and continuous process whose aim is to assess (evaluation, monitoring, securing, maintaining, or improving) the quality of the system or institutions of HE programs." (p. 32). These specific scientists generally distinguish QA in terms of internal and external: the former refers to the practices of an institution (intra-institutional practices), while the latter refers to those developed by an external organization (supra-institutional or inter-institutional schemes).

\section{Regulated Definitions of Quality and Quality Assurance}

Since 1994-1995, at a European level, a pilot project was conducted for evaluating quality in HE. Later, in 1998, a recommendation was made to Member States to establish a cooperation between European HE institutions on issues pertaining to QA. Additionally, in 1999, the Bologna Declaration (The European Higher Education Area, 1999) encourages European cooperation on QA in HE with a view to developing comparable criteria and methodologies, easily comparable diplomas, common European system of credits, and mobility for students and instructors. The European Network for Quality Assurance (ENQA) was founded in 2000, with the purpose of creating cooperation among the European countries in the field of quality assessment. ENQA undertook, in cooperation with other agencies (the European University Association, the European Association of Institutions in Higher Education, and the National Unions of Students in Europe), the task to establish a list of commonly acceptable principles, procedures and guidelines for QA, and a suitable system of assessment to be deployed by various agencies for internal and external assessment. Thus, currently, it is the European Association for Quality Assurance/ENQA that coordinates and formulates Standards and Guidelines of QA in the European Higher Education Area and develops good practices. All the above underscore that the enhancement and the assurance of quality in the field of HE is considered of high priority in Europe. However, a thorough investigation of all relevant, official publications of the European Union reveals no findings pertaining to quality concepts and criteria for distance or online Education. The sole exception is the paper Quality Assurance of e-learning which was published by ENQA in 2010. It is therein stated that no QA framework for e-learning had been developed. Furthermore, it is postulated that (e-learning) should not be assessed separately but as an integral part of HE” (European Association for Quality Assurance in Higher Education-ENQA, 2010). 


\section{Quality in Distance /Online Education}

Multiple growth rates within the global community create demands for new products-services and/or continuous quality improvement of the ones already on offer. Such growth necessitates the continuous effort of obtaining "competitive advantage" through the quality and value of the products-services. This value is rooted in the creation of products or services that are not only complying with pertinent quality definitions as they emerge, but also at each point they are afterwards properly evaluated. Thus, re-emerging or re-established value is an integral component of QA. According to Tremblay and Kish (2008, pp. 259261) the growing interest for the QA in HE is due, among others, to the emergence and/or expansion of private agencies, and to the diversification of the existing education and training-including the distance education and training-, all of which raise the demand for "better protection of consumers." Thus, distance and online education have already been recognized as a key factor in reshaping quality and QA (Albor, Lorduy \& Dau, 2014).

\section{The Context and the Revolutionized Definitions}

Meyer (2002, as cited in Shelton \& Isernhagen, 2012) underlines that the quality in HE is a complex and difficult concept, which depends on a number of factors that are derived from the student, the curriculum, the educational design, the technological means used, and the characteristics of the school. In this sense, the evaluation becomes a systematic process that comprises of collecting, processing, analyzing, and interpreting the data concerning individual objects; it is based on specific criteria designed to determine the degree of objectives' fulfillment, and provides feedback on the success and/or failure of the purpose of an educational system, its component parts included (Calder, 1995; Chinapah \& Miron, 1990; Dimitropoulos, 1991; Kassotakis, 1990; Makrakis, 1998). Clearly, quality evaluation and assurance within the emerging contexts do not lend themselves to simplistic insights and implementation. Such complexity, of course, should in no way serve as an excuse to ignore the need for assessment and promotion of quality education, as far as conventional and distance learning are both concerned. We, in fact, propose here that the necessity to rethink quality and QA in order to create operational definitions applicable to distance and online education, inevitably, reveals facets in conventional education whose evolutionary shifts necessitate novel definitions of quality and its assurance, too.

\section{The Quality Paradox in E-Learning}

Growth rates of distance and online learning posit increasing requirements for quality (Cavanaugh, 2002). Curiously, though, just as distance and online education morphed into an expanding player in the international educational domain, conflicting views concerning their effectiveness are abundant. Such concerns are not a novel occurrence (Sangrà, Vlachopoulos \& Cabrera, 2012). However, there had been an implicit assumption in the field that the very fact of continuous expansion of distance and online education would eventually allay those (Ellis, Ginns \& Piggott, 2009). However, as Casey (2008) argues, distance and online courses in HE seem to be more exposed to quality-related suspicion, compared to other types of education. Along the same lines, the Swedish Agency for Higher Education (2008) notes that the lack of quality is perceived as a limiting factor for the development of distance and online education. 
An investigation into the related literature reveals several appraisals of the overall quality of e-Learning. Lee and Dziuban (2002) consider that the overall success of e-Learning depends on the evaluation strategies of quality within an integrated program. Benson (2003) has investigated the different qualityrelated perceptions that stakeholders hold a discussion on, when considering an undergraduate distance or online program. According to her, these perceptions are related to the elimination of the "stigma" of distance education, the belief that quality means certification, the endorsement that quality is related to an efficient and effective development process and, finally, the view that quality concerns effective pedagogy.

In congruence, challenges for the QA of distance and online education are a matter of ongoing concern in the international literature. Frydenberg in 2002 (as cited in Ossiannilsson, 2012) following a review of available quality models for e-learning chunked quality elements into the following nine dimensions: "the administrative commitment, the technological infrastructure, the student services, the educational planning and development, the educators and educational services, the financial prosperity, the distribution of programs, the legal and regulatory requirements and the program evaluation" (p.65). Shelton (2011) also supports the notion that the way the nature and forms of stakeholders' motivations and policies impact quality necessitates ongoing and reliable support structures. In this research, it appears that motivation and policies weigh in more than technology, efficiency, and management. Ossiannilsson (2012), in her research on the comparative evaluation of e-learning in HE, revised the models of the international quality standards in ways applicable for institutions and quality assurance bodies alike. In addition, Jung and Latchem (2012) and Simonson (2015), outline what they deem as important dimensions concerning the processes involved in safeguarding the overall quality within institutions after they reviewed QA procedures in a large number of educational institutions and distance learning throughout the world. The researchers emphasize the need to adopt a systematic approach to QA, so that it is perceived as a process of continuous improvement, with a goal for agencies to escape from external controls and obtain an internal mentality of QA. They also claim that superior quality measures are results-focused and make the point of paying forward in quality as its compromise results in costly consequences.

\section{E-Learning Quality Assurance Case Studies}

Asia. The study of the International Council for Open and Distance Education-ICDE (2011) for QA systems in the Asian Pacific region indicates that almost all governments in the region have invested in, and are equipped with, systems for the certification and QA of HE, particularly distance education and elearning. And while the study of ICDE fully documents its systems, another study (Jung, Wong \& Belawati, 2013), funded by the International Research Centre (IDRC) on the quality of distance education in Asia, explored the operation of the institutions. The investigation revealed a variety of approaches to be considered for the development and improvement of QA systems in HE. It is also rich in useful information pertaining to the quality framework which has been adopted. The results indicate the formation of quality mentality as the most important factor, albeit difficult for such process to initialize in a controled fashion. Three clusters of factors appear critical in establishing quality mentality according to related research. Firstly, a quality mentality can be established and be sustainable when the staff in the field succeed in becoming familiar with the procedures. Secondly, a positive correlation is revealed between the strength of formal quality policies and the respective institutions' readiness to embrace incentives to work towards the development of a sustainable quality mentality. Finally, leaders emerge as pivotal both in seeing that 
material needs are adequately addressed and in providing staff and students with the necessary motivation. All the above findings are, furthermore, congruent with the results of Ossiannilsson's (2012) survey on the comparative assessment of e-learning in HE.

According to Jung, Wong, Li, Baigaltugs, \& Belawati (2011), the endorsement of the ISO9ooo system by many institutions in Higher Education showcases the implementation of commerce-inspired approaches in relation to quality. For instance, the Open University of China -among many others- has coined a multiple-indicator QA framework. These indicators revolve around five quality areas: development of teaching resources, management of teaching processes, learning support services, instructors' support services, and finally, learning settings (Du, Yang, Yin \& Zhang, 2009, as cited in Jung et al., 2011).

Further West. In Europe, according to ENQA (2005), educational institutions are obliged to ensure that for each and every study program, the appropriate teaching means are used to support the learners. Institutions are also responsible for the continuous improvement of the quality of academic programs via, not only the process of approval, monitoring, and formal review of the curriculum, but also through developing, for instance, learning goals, planning carefully, frequently evaluating curriculum, and individual course content. More recently, the European University Association (Gaebel, Kupriyanova, Morais, \& Colucci, 2014) performed a thorough investigation across both EU and non-EU countries' "state of the art" in e-learning, looking into various clusters of parameters. Results demonstrate that e-learning is offered to accommodate educational and economic incentives, and is tailored to learners' requests and needs for flexibility in time and place. Additionally, it addresses home-schooled learners and a wide range of professionals together with other lifelong learning students. Further incentives for institutional design and offering of e-learning include the best use of learning resources and the development of students' transversal competences as well as their business skills. Interestingly, all survey participants called for changes in the curricula and in assessment methods (Gaebel et al., 2014). It is, hence, apparent that European HE Institutions have revised their strategies to incorporate and implement E-learning. Crucially, this research underscores the innovative power inherent in e-learning. Nonetheless, institutions appear to be still lagging behind when it comes to the incorporation of a formal quality assurance framework for the improvement of e-learning programs. It is of great consequence that Gaebel, Kupriyanova, Morais, \& Colucci (2014) highlighted the requirement for integrating a quality assurance framework at both national and organizational level.

On the other side of the Atlantic, in 2000, the Institute for Higher Education Policy in Washington issued a report on the quality of distance education courses, aiming to determine their success criteria. In 2002, California State University published the rubric for online learning, providing guidelines for the "tracking" of exemplary online distance learning courses. At approximately the same time, Barker (2002) and Herrington, Herrington, Oliver, Stoney, and Willis (2001) published studies concerning the standards of elearning. All these publications include criteria in one or more of the following areas:

- Support from a quality assurance agency

- $\quad$ Course development and educational planning 
- Teaching and learning

- Course structure and resources

- Student and faculty support

- Evaluation and assessment

- Use of technology

- Products and e-learning services

The significance of these and similar efforts to define and examine the issues related to distance and online Education quality is undermined by the apparent drawback of an absence of a common, systematic, formative methodology for the measurement, and the assurance of quality (Chao, Saj \& Tessier, 2006).

\section{Quality Design Standards in E-Learning Courses}

The distance and online programs are complex and depend on several types of factors: technological, organizational, planning, etc. (Graham, Allen, \& Ure, 2003; Young, 2002). The worldwide available approaches and standards for e-learning quality management, assurance, and evaluation, are based on different methodologies, prime diverge dimensions, and contribute in various ways to the quality of a fully integrated service (European Distance and e-learning Netwrok-EDEN, 2003). According to Allen and Seaman (2015), one of the main criticisms of distance/online courses remain the poor quality concerns, while more positive evaluations declined in 2014 and 2015. Currently, conventional (face-to-face) instruction appears to be the hallmark of quality, especially when it comes to HE (Allen \& Seaman, 2015). The percept's validity is rather doubtful, though, considering that consensus on what "quality" actually involves is limited.

\section{Course Quality}

Whereas in the past, course "quality" was "measured" based on content, pedagogy, and learning results (Bremer, 2012), recent years saw a shift to a system that is related to process and considers a combination of factors that contribute to the educational experience and learning (Thair, Garnett, \& King, 2006). These factors include: students' needs, data, and information use for decision-making, administrative input, as well as learning outcomes' improvement.

Frydenberg (2002) notes that it is, precisely, the range of activities associated with the offer of e-learning services that necessitates a corresponding plurality of qualitative measurements of the offered product or service. Those quality measurements are addressed in the international community through the development of a number of approaches and quality standards (Manouselis \& Sampson, 2004). More specifically, Frydenberg (2002) identified the following two categories:

- E-learning-tailored quality approaches. These are typically focused on specific processes or elearning products, such e-learning materials' development, online course-design, and assessing the 
quality of e-learning services. Indicatively, we present the quality criteria of the European Treasury Browser (ETB) for the electronic educational material (Vicenza, Dippe, \& Vuorikari, 2002) and the model concerned with the process of development of the educational programs of the University of Essen (Pawlowski, 2002).

- General quality approaches. These are, usually, administration oriented or ones geared towards more general features of quality services and products, which can also be applied in e-learning. For example, one sees the international standard ISO 9000 the European model of excellence of the EFQM (European Foundation for Quality Management) and the evaluation model BAOL for the administration of open and flexible education / training centers (BAOL, 2001 as cited in Comité Européen de Normalisation-CEN, 2003).

Even though high-level quality of distance/online learning services and programs or courses is a selfevident objective, premises underlying their design and implementation sometimes hinder the objective's realization. Furthermore, quality measurements should encompass more than single, modular services, such as electronic educational material development or provision of an e-learning environment (Frydenberg, 2002). Manouselis and Sampson (2004) analyze and classify quality measurements in the following nine categories: readiness of the organizational and administrative structure of the organization to meet the requirements, required technological infrastructure availability, student services, instructional planning (including development of educational material), level of instruction and faculty training, electronic services access protocols, financial return, program compatibility with the relevant regulations and laws, and program assessment procedures. Significantly, these factors should be attended to independently and holistically from the early phases of program design until the program's many subsequent evaluations. Efficient system design requires that the different factors must be foreseen in the designing phase of the program, so as to allow every component to work together effectively, contributing to the effective function of the system itself (Lockee, Moore, \& Burton, 2002).

\section{Course Design Quality Basics}

According to Tham and Werner (2005), there is no specific model containing the "one size fits all" factors for program quality, since each one is unique. Thus, factors are adjusted within each case to the needs and objectives of the respective educational process. Tham and Werner (2005) further identify the following critical areas: a) Planning the educational process, b) Lesson presentation, c) Academic issues and e) Student Affairs.

Despite this need for flexibility, a variety of quality labels and certifications have been developed to assure course quality. Particularly, the certification ECBCheck that was created by the European Foundation for quality in e-Learning, and the E-xcellence model that was created by the European Union for teaching in distance education, are both aimed at measuring the substantial quality of e-learning curriculum (Devedžič, Šćepanović, \& Kraljevski, 2011). More analytically, the ECBCheck certification analyzes programs' organization, their objectives relevance to users' needs, content quality, program planning, communication media planning, technology, assessment, and examination. On a slightly different note, the E-xcellence 
model measures strategic management, curriculum planning, course planning, course delivery, and, support of faculty and students (Williams, Kear, \& Rosewell, 2012).

\section{Course Design Quality Standards}

In spite of the differences in the available literature regarding different aspects and criteria that affect programs' quality and effectiveness, there is a notable consensus that, current criteria should be adapted to the needs, objectives, and features of each program. Many organizations have complied with general standards such as ISO 9000: 2000 or EFMQ Excellence Model, but as far as e-learning is concerned, specific requirements are in the process of being developed. The new standard ISO / IEC 19796-1 (International Standards Organization-ISO, 2005) provides a frame of reference to describe the quality approaches (Reference Framework for the Description of Quality approaches). A reference framework gives guidance for issues that need to be addressed and potential solutions. The model is a tool for quality development in the field.

Establishing standards is intended to afford a measure for QA of e-Learning courses, so that the students' needs are better served (The Pennsylvania State University, 2008). The University of Pennsylvania identifies 12 QA course design standards: Navigation, Student Orientation, Curriculum, Communication and Availability, Course Resources Requirements, Technical Support, Accessibility Requirements, Learning Objectives, Learning and Assessment Activities, Copyright Requirements, Functionality, and Reports for course improvement.

Meanwhile, the Swedish National Agency of HE (2008) has initiated a project designed to define quality in Distance/Online Education. Based on an analysis of European policies and projects, practices from national organizations, and on empirical data regarding e-learning quality, the following crucial areas have been identified: material/content, structure/virtual environment, communication, cooperation and interactivity, student assessment, flexibility and adaptability, support (student and staff), staff qualifications and experience, vision and institutional leadership, and resource allocation.

In this context, the Foundation of the University of California, designed a new rubric named Quality Online Learning and Teaching (California State University-Chico, 2014), which includes 54 goals distributed in nine distinct areas: course overview - introduction, assessment and evaluation of students' learning; learning materials and resources utilized; student interaction - community, facilitation and teaching; teaching and learning technology; academic and technical support for the students; accessibility and universal design; and summary - synopsis and lesson connection.

Finally, we conclude with the Quality Suite, provided by the Consortium of Organizations for postsecondary education, eCampusAlberta in Canada, which describes a number of "standards" useful for course design and online curriculum development (eCampusAlberta, 2012):

a) the Quality Standards White Paper, a collaborative document guiding the initial development of quality standards for the eCampusAlberta consortium,

b) the eLearning Rubric, which is available in print and in online format. 
c) the Institutional Curricula Self-Assessment Score card and

d) the Essential Quality Standards (EQS).

\section{E-Learning Community's Reception of Quality Standards Value}

Pawlowski (2007) emphasizes that there has often been a misconception concerning the standards of quality, especially within the educational community. This is partly explained by the belief that quality standards limit flexibility and creativity, and they require extreme, additional effort. However, the newly established standards of quality provide a basic framework that can assist organizations to develop quality systems according to their own, specific requirements. According to Pawlowski (2007), the quality standards provide harmonized consensus concepts for managing, securing, or assessing quality. Moreover, he outlines that while there is an availability of a wide range of standards in the fields of learning, education, and training, we may be able to form a categorization of three distinct types:

- General quality standards, which provide concepts for quality management, regardless of the field of application.

- Specific quality standards, which foster quality management within the procedures or educational products.

- Pertinent standards, which are used for managing or ensuring specific aspects of quality.

The development and use of appropriate tools for describing, categorizing, and analyzing the different quality approaches, constitutes an important factor in supporting stakeholders (e.g., HE institutions, vocational training centers, businesses developing training materials, and/or electronic software for learning) to evaluate and upgrade their services quality. Meanwhile, corresponding tools support organizations to select, formulate and improve the quality standards for e-learning (Pawlowski, 2003).

The issue of quality is a current concern for everyone involved in training and education, both for face-toface and distance/online education. However, it poses perhaps a higher bet for Open and Distance Learning (ODL), given the latter's virtual nature and the physical distance between learners and teachers. Importantly, the variety of distance/online education offerings and the associated pedagogical models and adopted technological tools require an intense focus on the quality of these offers as they are situated competitively within a global context (Zghibi, Zghidi, \& Chater, 2012).

Nevertheless, the implementation of a quality approach in distance/online education is complicated by the fact that the concept of customer becomes multiple and the quality depends not only on the producer but also on the client's involvement (Vanderspelden, 2002). This understanding is especially pertinent to a flexible application of quality models in the field of training, since the latter is not a linear and reproducible industrial process.

According to Zghibi, Zghidi, and Chater, (2012), it is imperative to engage the different actors involved in distance/online education: developers, administrators, governments, providers, teachers, and learners to 
ensure that the technology used adequately meet their needs. That said, the standardization bodies constantly work to develop and finalize quality standards that should be respected by distance/online education providers. Along the same lines, Grifoll et al. (2010) suggest that "the use of standards and guidelines for QA in the European HE is not contradictory to the generation of relevant opportunities for innovation and enhancement of the QA process in HE, and in e-learning in particular. In fact, this can be seen as a catalyst for the definition of new concepts of quality in the coming future" (p.7). Kovanovic et al. (2015) highlight that “...distance learning, when properly planned and supported by the right combination of technology and pedagogy, is equivalent to, or -in some cases- more effective than traditional face-to-face classroom teaching" (p.7).

As far as the learners' perceptions are concerned, it is important to mention that a good number of existing studies describe their high satisfaction with online programs for a number of reasons. Researching what satisfies learners in distance and online education could be a fundamental factor in designing quality assurance models. More analytically, they mention as a very important aspect the flexibility and convenience to learn at their own pace, as well as the freedom from time and geographical limitations. Furthermore, they underline that distance and online education are more affordable (due to the possibility they offer to study from home), and they give special emphasis on the self-regulated way of learning, the access to lifelong learning and the efficiency and consistency of the learning resources (Anderson, 2003). Importantly, technological (communication, interaction, and learning) tools' use ranks high on satisfaction factors. In addition, learners find appeal in the individually tailored support being offered, and the learnerto-learner and learner-to-instructor high level of interaction (Vlachopoulos \& Tsokkas, 2015). It is, however, found that non-verbal communication signs such as wrinkles, smiles, facial expressions, and body language are more likely to appear in face-to-face interaction. The absence either of verbal or non-verbal communication may lead to misinterpretation or misunderstanding difficulties, whereas personal contact in traditional classrooms or interactive contact via online forums or written messages significantly affect students' performance.

Anonymity, on the other hand, seems to work both ways; some researchers detect more academic cheating rates in online courses, due to the lack of face-to-face interaction or to the greater ease in accessing resources (Young, 2013). Others find that online students tend to cheat less than the face-to-face ones (Miller \& Young-Jones, 2012). Notably, online education allows students to get engaged in scholar scientific networks and summer courses, while it affords people with disabilities access to education. Crucially, the online way of teaching and learning may result in better learning outcomes and significantly higher scores in exams than in conventional education (Wang, Shannon, \& Ross, 2013). This finding seems to be correlated with increased student interaction with peers, the instructor, and the material. Students strongly value distance-learning environments, because they achieve higher quality educational outcomes without having to endure the occasional boredom of a traditional classroom (Fortune, Spielman, \& Pangelinan 2011). Harrington and Loffredo (2010) found that students prefer online programs, because they are convenient and give them the chance to study in a more attractive way through of use information technology. 
On the other hand, distance learning involves a lot of self-regulation and self-motivation, because students need to find the time that needs to be invested in order to achieve learning outcomes. As far as the instructors are concerned, distance/online courses are viewed as more demanding and time consuming (Bailey \& Card, 2009).

\section{Next Steps}

The exhaustive meta-analysis of available literature that we undertook for the purposes of this study resulted in the outlining of the following focal areas of interest for QA design and implementation in HE as it has been shape-shifting after the extended integration of distance and online education.

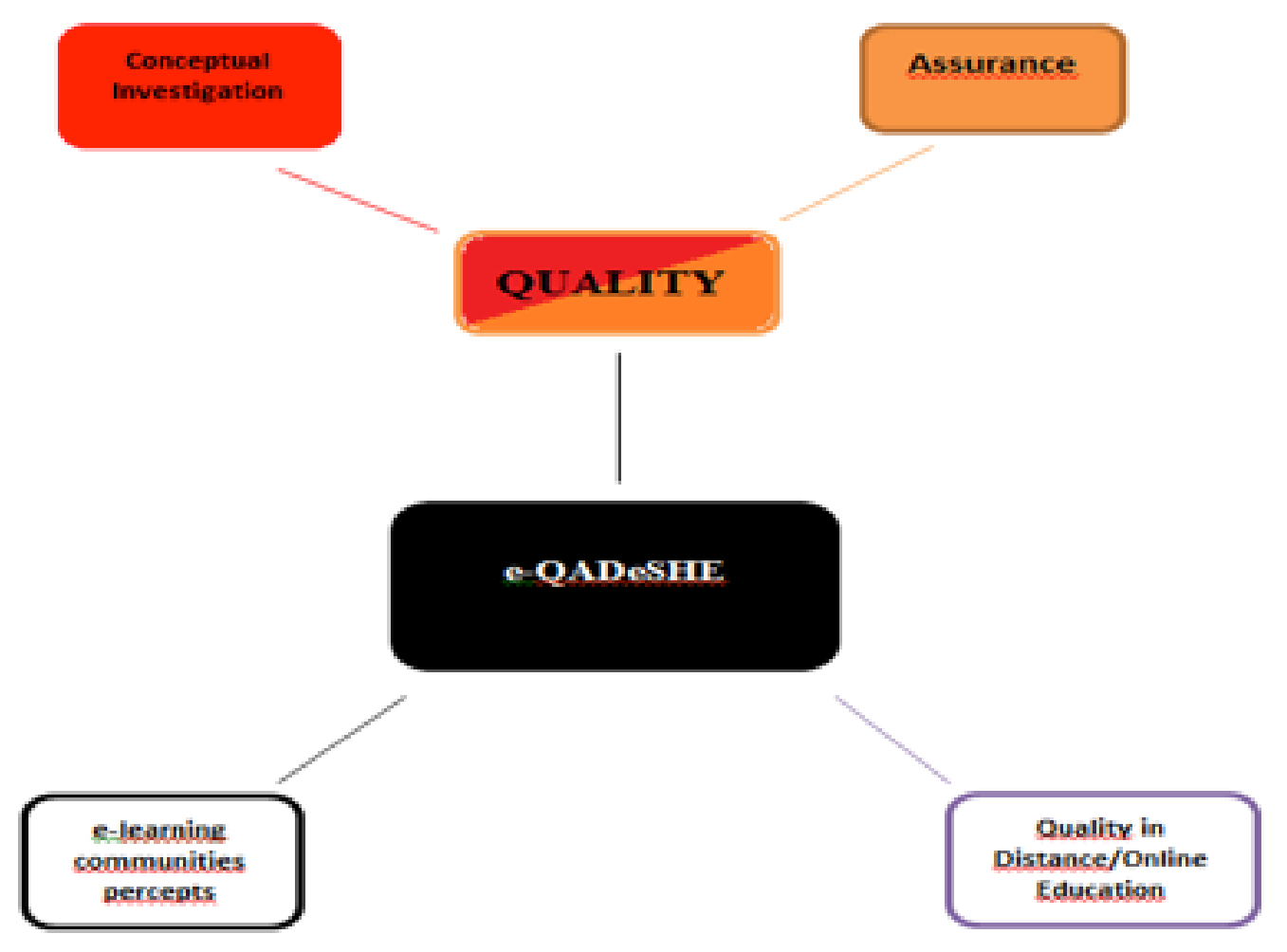

Figure 1. e-QADeSHE (e-learning Quality Assurance Design Standards in Higher Education): Focal Areas. Our outline of focal areas of interest for QA design and implementation in HE after the extended integration of distance and online education.

Our paper, and the e-QADeSHE project, has further identified a multitude of sub-areas within each of the main focal areas (Figure 2), ripe for a cascade of further, future studies. 


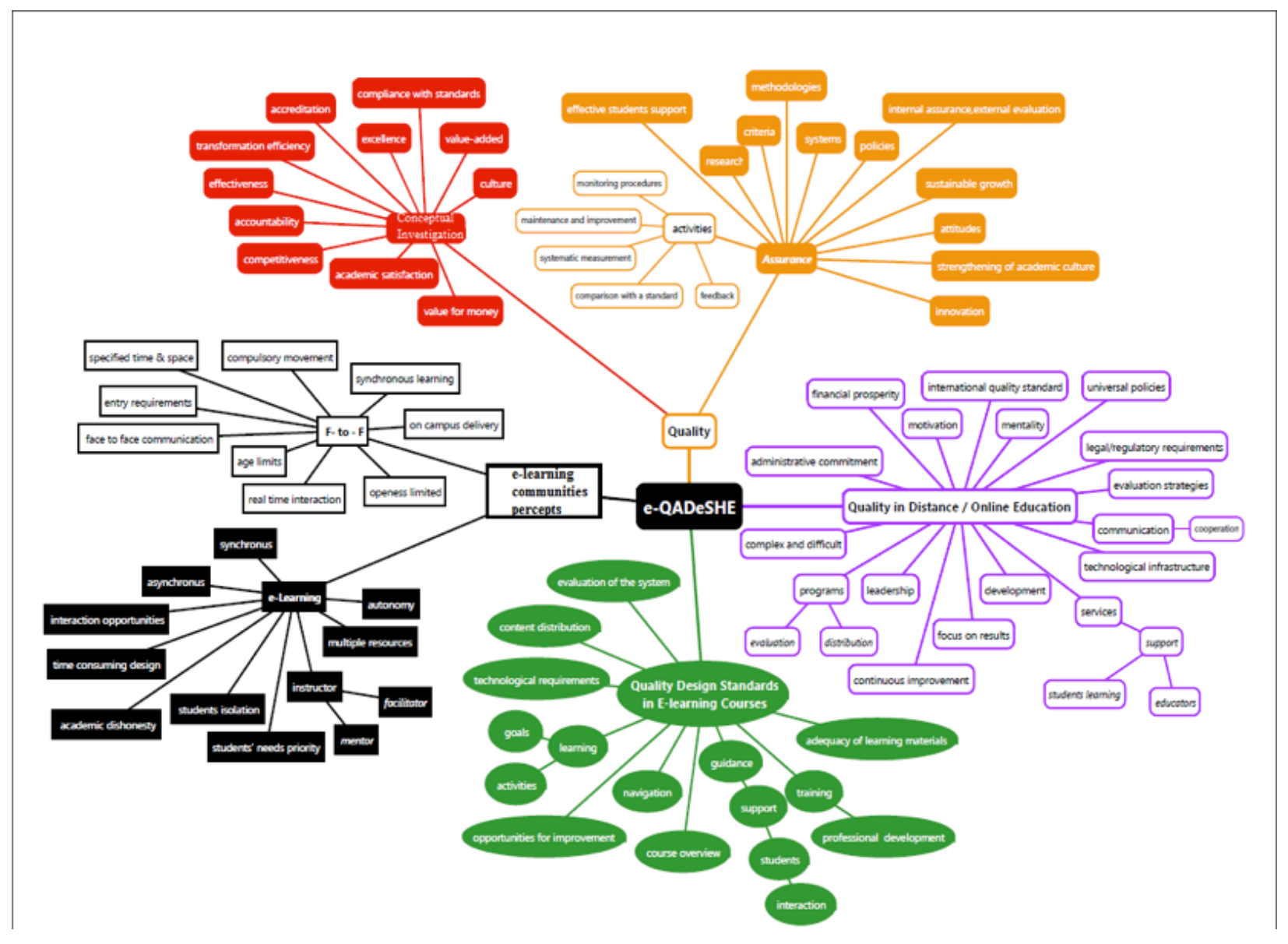

Figure 2. The roadmap of e-QADeSHE project. Sub-areas and the dynamics among them included.

These future studies will be instrumental in pruning this first roadmap and in delineating the exact dynamics and processes among the various factors. More analytically, the conceptual investigation on Quality has provided evidence that the concept is directly related to Accreditation, Effectiveness, Excellence, Satisfaction, Competitiveness, and Accountability. To assure Quality, the literature review demonstrated that it is of utmost importance to provide solid faculty and student support mechanisms, internal and external evaluation processes, strengthening of the academic culture, as well as constant collaboration and interaction with the stakeholders to ensure ongoing improvement. In the context on online HE, QA is linked with the technological infrastructure, the assessment and evaluation systems, and the students' performance and satisfaction, while it depends on international standards and universal policies. Finally, the identification of quality online course design standards, accepted and recognized by the different e-learning communities, demonstrates that it is feasible to build a shared framework for 
assuring quality, which can be developed by scholars and policy makers of the sector. The intention behind this work has been to shape a commonly agreed upon framework of key parameters that will be fruitful in fostering testable hypotheses and models regarding the various variables' intertwined relationships. The field has been in need of a clearly articulated mapping of the territory. It is our hope that our assiduous review of all related research across all dimensions involved in providing, sustaining, and enjoying Higher Education- as it has evolved- has resulted in a first roadmap to guide future steps for institutions, policy makers, and scholars alike.

\section{Acknowledgements}

This research is part of the "e-QADeSHE" project, which was sponsored by Laureate International Universities. The research team of "e-QADeSHE," led by the author was made up of A. Makri, G. Katsimente, G. Tsokkas \& A. Chouchourelou.

\section{References}

Albor, G. R., Lorduy, V. G., \& Dau, M. A. (2014). Quality of higher education for distance and virtual learning. Investigación \& Desarrollo, 22(1), 79-120.

Allen, I. E., \& Seaman, J. (2015). Grade level: Tracking online learning in the United States. Wellesley, MA: Babson Survey Research Group and Quahog Research Group, LLC. Retrieved from http://www.onlinelearningsurvey.com/reports/gradelevel.pdf

Anderson, T. (2003) Critically examining distance education practice. In M. Moore (Ed.), A century of distance education in the United States. Ohio: Ohio State University.

Anis, A., Abdullah, Z., \& Islam, R. (2014). Defining quality education in higher learning institutions: Divergent views of stakeholders. International Journal of Arts \& Sciences, 7(1), 375-385.

Bailey, C. J., \& Card, K. A. (2009). Effective pedagogical practices for online teaching: Perception of experienced instructors. The Internet and Higher Education, 12(3), 152-155.

Barker, K. C. (2002). Canadian recommended e-learning guidelines (CanREGs). Retrieved from http://www.col.org/newsrelease/CanREGs\%20Eng.pdf

Benson, A. D. (2003). Dimensions of quality in online degree programs. The American Journal of Distance Education, 17(3), 145-149. 
Bogue, E. G. (1998). Quality assurance in higher education: The evolution of systems and design ideals. New Directions for Institutional Research, 99, 7-18.

Bremer, C. (2012). Enhancing e-learning quality through the application of the AKUE procedure model. Journal of Computer Assisted Learning, 28(1), 15-26.

Calder, J. (1995). Programme evaluation and quality: A comprehensive guide to setting up an evaluation system. London: Open University.

California State University - Chico, (2002). Rubric for Online Instruction. Retrieved from http://www.csuchico.edu/eoi/

Casey, D. M. (2008). A journey to legitimacy: The historical development of distance education through technology. TechTrends: Linking Research \& Practice to Improve Learning, 52(2), 45-51.

Cavanaugh, C. (2002). Distance education quality: Success factors for resources practices and results. In R. Discenza., C. Howard., \& K. Schenk (Eds.), Design of effective distance learning programs, 173-191. Hershy, PA: Idea Group Publishing.

Conseil canadien sur l'apprentissage-CCA(2009). À la hauteur : le défi à démontrer la qualité de l'enseignement postsecondaire au Canada. Les défis de l'enseignement postsecondaire au Canada [Measuring up: the challenge to demonstrate the quality of postsecondary education in Canada. The challenges of post-secondary education in Canada], Le Conseil, 7-8.

Chao, T., Saj, T., \& Tessier, F. (2006). Establishing a quality review for online courses. Educause Quarterly, 3. Retrieved from http://er.educause.edu/articles/2006/1/establishing-a-qualityreview-for-online-courses

Chinapah, U., \& Miron, G. (1990). Evaluating educational programs and projects: Holistic and practical considerations. Socio-economic Studies, 15, Paris: UNESCO

Comité Européen de Normalisation -CEN (2003). Quality assurance standards. Brussels: CEN.

Commission Européenne. (2009). Améliorer la qualité de l'enseignement supérieur. Une étude du programme Tempus (Improving quality in higher education. A study of the program Tempus). Belgium: Publications Office.

Conseil Supérieure de l'Education de Québec-CSE. (2012). L'assurance qualité à l'enseignement universitaire: Une conception à promouvoir et à mettre en œuvre (Quality assurance in university education: A design to promote and implement). Quebec : Bibliothèque et Archives nationales du Québec.

Dagles, I. (2008). The Research on the quality of the System of Primary and Secondary Education. Athens: Pedagogical Institute. 
Devedžič, V., Šćepanović, S., \& Kraljevski, I. (2011). E-Learning benchmarking methodology and tools review (Project Deliverable No. 1.3). Serbia: University of Kragujevič. Retrieved from http://www.dlweb.kg.ac.rs/files/DEV1.3\%20EN.pdf

Dimitropoulos, E. (1991). Educational evaluation. Athens: Ed. Grigoris.

eCampusAlberta. (2012). Quality suite. Retrieved from www.ecampusalberta.ca/members/ memberresources/quality-suite

European Distance \& e-Learning Network-EDEN (2003, June). The quality dialogue - Integrating quality cultures in flexible, distance and elearning workshop. Proceedings of the 2003 EDEN Annual conference, Rhodes, Greece, 15-18.

Ellis, R.A., Ginns, P., \& Piggott, L. (2009). E-learning in higher education: Some key aspects and their relationship to approaches to study. Higher Education Research \& Development, 28(3). 303-318.

European Association for Quality Assurance in Higher Education-ENQA (2005). Standards and guidelines for quality assurance in the European higher education area (ESG). Retrieved from http://www.enqa.eu/wp-content/uploads/2015/o9/ESG_3edition.pdf

European Association for Quality Assurance in Higher Education-ENQA (2010). Quality assurance of elearning. Workshop Report 14. Retrieved from http://www.enqa.eu/indirme/papers-andreports/workshop-and-seminar/ENQA wr_14.pdf

Fortune, M. F., Spielman, M., \& Pangelinan, D. T. (2011). Students' perceptions of online or face-to-face learning and social media in hospitality, recreation and tourism. MERLOT Journal of Online Learning and Teaching, 7(1). Retrieved from http://jolt.merlot.org/vol7no1/fortune_0311.pdf

Frydenberg, J. (2002). Quality standards in e-learning: A matrix of analysis. International Review of Research in Open and Distance Learning, 3(2). Retrieved from http://www.irrodl.org/index.php/irrodl/article/view/109/189

Gaebel, M., Kupriyanova, V., Morais, R., \& Colucci, W. (2014). E-learning in European higher education institutions. Brussels: European University Association (EUA).

Graham, C. R., Allen, S., \& Ure, D. (2005). Benefits and challenges of blended learning environments. In M. Khosrow-Pour (Ed.), Encyclopedia of information science and technology (pp. 253-259). Hershey, PA: Idea Group.

Grifoll, J., Huertas, E., Prades, A., Rodríguez, S., Rubin, Y., Mulder, F., \& Ossiannilsson, E. (2010). Quality assurance of e-learning. Helsinki: European Association for Quality Assurance in Higher Education. 
Harrington, R., \& Loffredo, D. A. (2010). MBI personality type and other factors that relate to preference for online versus face-to-face instruction. Internet and Higher Education, 13, 89-95.

Harvey, L., \& Green, D. (1993). Defining quality. Assessment and Evaluation in Higher Education, 18(1), 9-34.

Harvey, L. (2004). Analytic quality glossary. Retrieved from http://www.qualityresearchinternational.com/glossary/

Harvey, L. (2007). The epistemology of quality. Perspectives in Education, 25(3), 1-13.

Harvey, L. (2008, May 27 \& 28). Les initiatives canadiennes d'assurance de la qualité vues dans le contexte international. Colloque sur l'assurance de la qualité du CMEC, Toronto, CA.

Herrington, A., Herrington J., Oliver, R., Stoney, S., \& Willis, J. (2001). Quality guidelines for online courses: The development of an instrument to audit online units. In Proceedings of the Annual Conference of the Australasian Society for Computers in Learning in Tertiary Education: Meeting at the Crossroads, ED 467943 in the ERIC database.

International Council for Open and Distance Education- ICDE (2011). Regulatory frameworks for distance education: A pilot study in the Southwest Pacific/South East Asia Region. Retrieved from http://www.icde.org/filestore/Regulatory_Framework/RegulatoryFrameworksforDEfinalreport2 .pdf

International Standards Organization-ISO8402 (1994). Quality management and quality assurance Vocabulary. Retrieved from http://www.iso.org/iso/catalogue detail.htm?csnumber=20115

International Standards Organization- ISO, (2005). ISO/IEC 19796-1:2005 Information technology -Learning, education and training - Quality management, assurance and metrics -- Part 1: General approach. Retrieved from http://www.iso.org/iso/catalogue detail?csnumber=33934

Jung, I., Wong, T. M., Li, C., Baigaltugs, S., \& Belawati, T. (2011). Quality assurance in Asian distance education: Diverse approaches and common culture. International Review of Research in Open and Distance Learning, 12(6), 63-83.

Jung, I., \& Latchem, C. (Eds.). (2012). Quality assurance and accreditation in distance education and elearning. Models, policies and research. New York: Routledge.

Jung, I., Wong, T., \& Belawati, T. (2013). Quality assurance in distance education and e-learning. Challenges and solutions from Asia. Los Angeles: SAGE.

Kassotakis, M. (1990). The assessment of student performance. Athens: Grigoris. 
Kontogeorgos, A. (2012). Quality assurance in higher education. Good practices. Retrieved from http://modip.teilam.gr/files/1 Basikes ennoies.pdf [in Greek].

Kovanović, V., Joksimović, S., Skrypnyk, O., Gašević, D., Dawson, S., \& Siemens, G. (2015). The history and state of online learning. In G. Siemens, Gašević, D. \& Sawson, S. Preparing for the digital university: A review of the history and current state of distance, blended, and online learning. Retrieved from http://linkresearchlab.org/PreparingDigitalUniversity.pdf

Lee, J., \& Dziuban, C. (2002). Using quality assurance strategies for online programs. Educational Technology Review, 10(2), 69-78.

Lillis, T. \& Curry, M. J. (2015). The politics of English, language and uptake. AILA Review 28, 127-150.

Lockee, B., Moore, M., \& Burton, J. (2002). Measuring success: Evaluation strategies for distance education. Educause Quarterly, 1, 20-26.

Makrakis, V. (1998). Evaluation of open and distance education systems. In In D. Vergidis., A. Lionarakis., A. Lykourgiotis., B. Makrakis., \& Ch. Matralis (Eds.), Open and distance education: Institutions and operations (pp. 245-301). Patras: Hellenic Open University. [in Greek]

Manouselis, N., \& Sampson, D. (2004). A multi-criteria model to support automatic recommendation of e-learning quality approaches In Proceedings of the 16th World Conference on Educational Multimedia, Hypermedia and Telecommunications (ED-MEDIA 2004), Lugano, Switzerland.

Martin, M., \& Stella, A. (2007). Assurance qualité externe dans l'enseignement supérieur: les options (External quality assurance in higher education : the options). Paris: UNESCO, Institut international de planification de l'éducation.

Miller, A., \& Young-Jones, A. D. (2012). Academic integrity: Online classes compared to face-to-face classes. Journal of Instructional Psychology, 39(3-4), 138-150.

Nicholson, K. (2011). Quality assurance in higher education: A review of the literature. Hamilton, CA.: McMaster University.

Ossiannilsson, E. (2012). Benchmarking e-learning in Higher Education: lessons learned from international projects (Doctoral dissertation, University of Oulu Graduate School). Retrieved from http://herkules.oulu.fi/isbn9789526200415/isbn9789526200415.pdf

Pawlowski, J. (2002). Reusable models of pedagogical concepts - A framework for pedagogical and content design. In Proceedings of 14th World Conference on Educational Multimedia, Hypermedia and Telecommunications (ED-MEDIA 2002), Denver, USA, 1536-1568. 
Pawlowski, J. (2003, July). The European quality observatory (EQO): Structuring quality approaches of elearning. In Proceedings Of the 3rd IEEE International Conference on Advanced Learning Technologies (ICALT 2003), Athens, Greece.

Pawlowski, J. M. (2007). The new quality standard for e-learning: Enabling global quality development. Retrieved from http://www.initiatives.refer.org/Initiatives-2005/document.php?id=337

Prisacariu, A., \& Shah, M. (2016). Defining the quality of higher education around ethics and moral values. Quality in Higher Education, 22(2), 1-15.

Sangrà, A., Vlachopoulos, D. \& Cabrera, N. (2012). Building an inclusive definition of e-learning: An approach to the conceptual framework. The International Review of Research in Open and Distance Learning, 13(2), 145-159. Retrieved from http://www.irrodl.org/index.php/irrodl/article/view/1161/2146

Sârbu, R., Ilie, A. G., Enache, A. C., \& Dumitriu, D. (2009). The quality of educational services in Higher Education - Assurance, management or excellence? Amfiteatru Economic, 8 (26), 383-392.

Schindler, L., Puls-Elvidge, S., Welzant, H., \& Crawford, L. (2015). Definitions of quality in higher education: A synthesis of the literature. Higher Learning Research Communications, 5(3), 3-13.

Shelton, K. (2011). A review of paradigms for evaluating the quality of online education programs. Online Journal of Distance Learning Administration, 14(1). Retrieved from https://www.learntechlib.org/p/52626

Shelton, K., \& Isernhagen, J. (2012). A quality scorecard for the administration of online education programs. Presentation at the NCPEA 66th Annual Conference, Kansas City, MO.

Simonson, M. (2015). Accreditation and quality in distance education. Distance Learning, 12(1), 27-28.

Swedish National Agency for Higher Education. (2008). E-learning quality aspects and criteria for evaluation of e-learning in higher education (Report 2008:11 R). Stockholm: Högskoleverkets.

Thair, A., Garnett, P., \& King, S. (2006). Quality assurance and change in higher education. In L. Hunt., A. Bromage., \& B. Tomkinson (Eds.), The realities of change in higher education: Interventions to promote learning and teaching (pp. 52-63). London: Routledge.

Tham, C. M., \& Werner, J. M. (2005). Designing and evaluating E-learning in higher education: A review and recommendations. Journal of Leadership \& Organizational Studies, 11(11), 15.

The European Higher Education Area. (1999). The bologna declaration of 19 June 1999. Retrieved from http://www.ehea.info/article-details.aspx?ArticleId=3 
The Pennsylvania State University. (2008). Penn State quality assurance e-learning design standards. Pennsylvania: Pennsylvania State University.

Tremblay, K., \& Kis, V. (2008). Assuring and improving quality. In P. Santiego, Trmblay, K., Basri, E. \& Arnal E. Tertiary education for the knowledge society - Volume 1: Special features: Governance, funding, quality (pp. 259-322). Paris: Organisation de coopération et de développement économiques.

Vanderspelden, J. (2002). La qualité dans le champ de la formation ouverte et à distance (Quality in the field of open and distance learning). Retrieved from http://ressourcesv2.emotive.com/frontblocks/news/papers.asp?id papers=1243\&ID THESAURUS NODES=1047

Vicenza, B., Dippe, G., \& Vuorikari, R. (2002). Recommendation on quality assurance and selection of resources for the ETB network. Retrieved from http://www.en.eun.org/etb/survey/d3.2.pdf

Vlachopoulos, D. \& Tsokkas, G. (2015). The traits that facilitate successful student performance in Distance Education. The case of the Distance Education Unit at the European University Cyprus. International Journal of Social, Education, Economics and Management Engineering, 9(1), 264267.

Vroeijenstijn, A. (1995). Governments and university: Opponents or allies in quality assurance? Higher Education Review, 27(3).

Wang, C., Shannon, D. M., \& Ross, M. E. (2013). Students' characteristics, self-regulated learning, technology self-efficacy, and course outcomes in online learning. Distance Education, 34(3), 302323.

Williams, K., Kear, K., \& Rosewell, J. (2012). Quality assessment for e-learning: A benchmarking approach (2nd ed.). Herleen, The Netherlands: European Association of Distance Teaching Universities. Retrieved from http://oro.open.ac.uk/34632/

Woodhouse, D. (1999). Quality and quality assurance. In H. de Wit, \& J. Knight (Eds.). Quality and internationalisation in higher education (pp. 29-43). Paris: Organisation for Economic Cooperation and Development.

Young, J. R. (2002). "Hybrid" teaching seeks to end the divide between traditional and online instruction. Retrieved from http://chronicle.com/article/Hybrid-Teaching-Seeks-to/18487

Young, J. R. (2013). Online classes see cheating go high tech. Education Digest, 78(5), 4-13.

Zavlanos, M. (2003). Total quality management in education. Athens: Stamoulis.

Zghibi, R., Zghidi, S., \& Chater, O. (2012). Les normes e-learning comme garant de qualité de l'enseignement à distance dans le contexte éducatif tunisien: le cas de l'UVT (The e-learning 
Assuring Quality in E-Learning Course Design: The Roadmap

Vlachopoulos

standards as a guarantee of quality distance education in the Tunisian educational context: the case of UVT). Retrieved from http://www.frantice.net/

\section{Athabasca}

University

(c) () 